The Free Internet Journal

for Organic Chemistry
Paper

Arkivoc 2019, part v, 279-291

\title{
Temperature-controlled synthesis of $\mathrm{N}$-acyl anthranilamides and quinazoline-4- ones via Pd-catalysed cascade consisting of isocyanide insertion
}

\author{
Irfan Khan, ${ }^{\text {a Jaybir Singh, }}{ }^{\text { Imran Khan, }}{ }^{c}$ Sunil Dutt, ${ }^{c}$ Shahnawaz Khan, ${ }^{* d}$ and Vikas Tyagi*c \\ ${ }^{a}$ Coordination Chemistry Laboratory, Department of Chemistry, Mohan Lal Sukhadia University, Udaipur, \\ Rajasthan, India \\ ${ }^{b}$ Department of Pharmacy, Dr. B. R. Ambedkar University, Agra-282002, India \\ 'School of Chemistry and Biochemistry, Thapar Institute of Engineering and Technology, Patiala-147004, \\ Punjab, India \\ ${ }^{d}$ Department of Chemistry, Bhupal Nobles University, Udaipur, Rajasthan, India \\ Email:vikas.tyagi@thapar.edu vtyagi1985@gmail.com
}

\section{Abstract}

A one step synthesis of functionlized $\mathrm{N}$-acyl anthranilamide via Pd-catalyzed carboxamidation of $o$-halo substituted $N$-phenylamide consisting of isocyanide insertion followed by oxidation of the imine intermediate has been achived successfully. Furthermore, at elevated temprature $\left(160^{\circ} \mathrm{C}\right)$ the Pd-catalyzed tandem reaction afforded functionlized quinazolin-4-one in a single step without the isolation of $\mathrm{N}$-acyl anthranilamide and proceed through carboxamidation/de-t-butylation/cyclodehydration cascade. This work extends the application of isocyanide insertion chemistry for synthesizing diverse $\mathrm{N}$-heterocycles by transition metal catalysed sequential reactions in a single step.

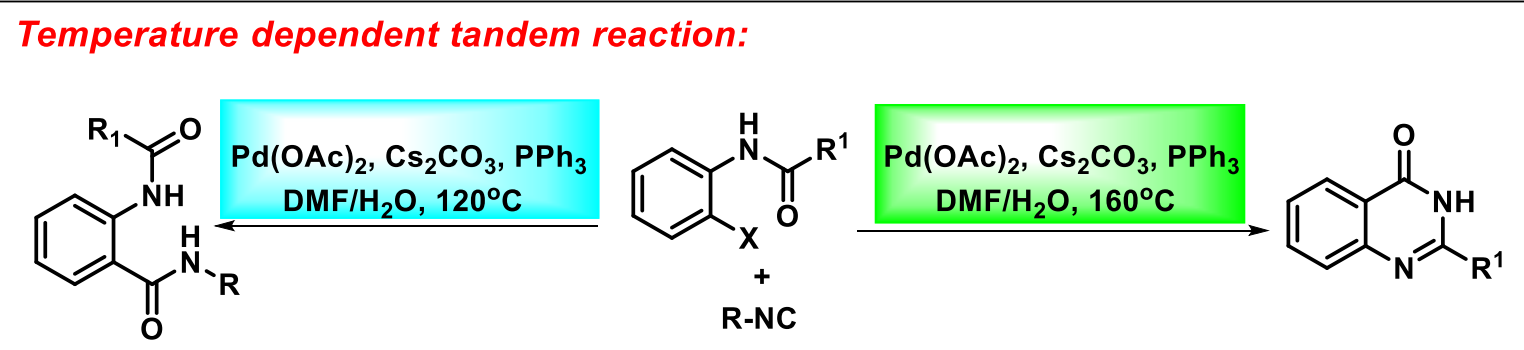

Keywords: N-acyl anthranilamide, quinazoline-4-one, isocyanide, palladium, cascade reactions 


\section{Introduction}

Transition metal catalysed sequential reactions (tandem) for the syntheses of functionalized heterocycles are on high demand due to the presence of less purification and separation steps and production of fewer numbers of toxic substances throughout the synthesis. ${ }^{1-4}$

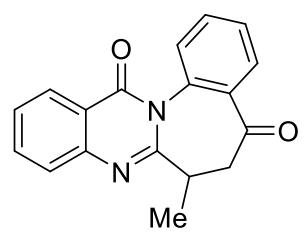

Circumdatin F

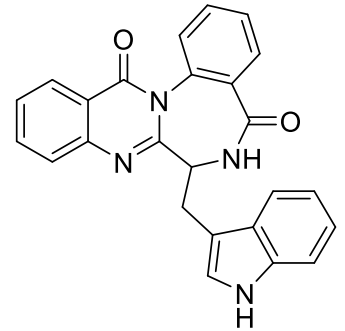

Asperlicin C

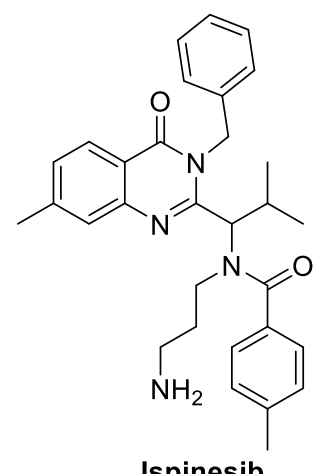

Ispinesib

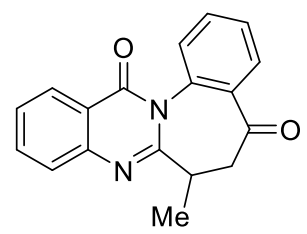

Sclerotigenin

Figure. 1. Some biologically active molecules and natural products containing $\mathrm{N}$-acyl anthranilamide and quinazolin-4-one motifs.

Despite the progress in this area, ${ }^{5-7}$ we are lagging behind in the development of new one step methods proceeds through a sequence of reactions for the synthesis of nitrogen-containing heterocycles, those are ubiquitous and integral pharmacophoric units prevalent in a diverse variety of bioactive natural products, synthetic drugs, pharmaceutical and agrochemicals. ${ }^{8-9}$ Among these nitrogen-containing heterocycles $\mathrm{N}$-acyl anthranilamide and quinazolin-4-one cores and their derivatives constitute an imperative class of compounds with a diverse therapeutic and pharmacological properties such as antimicrobial, anticonvulsant, anticancer, antimalarial, antihypertensive, anti-inflammatory, anti-diabetic, antitumor, anticholinesterase, dihydrofolate reductase inhibition, cellular phosphorylation inhibition, and kinase inhibitory activities, also, they are part of a number of natural products (Figure 1). ${ }^{10-18}$ Due to the exhibition of a number of biological activities and part of a number of natural products, the development of new methods for the synthesis of $\mathrm{N}$-acyl anthranilamide and quinazoline-4-one skeleton have grabbed lot of attention in recent years. ${ }^{19-20}$ In general, we use anthranilic acids for synthesizing corresponding anthranilamide, although, this process is inherently restricted by the limited range of commercially available anthranilic acids. ${ }^{21}$ Additionally, various methods have been reported for the synthesis of $\mathrm{N}$-acyl anthranilamide and quinazoline-4-one skeleton in recent years (Scheme 1).22-25 However, mostly of them have certain drawbacks such as multistep, longer reaction time, the limited selection of commercially available starting materials and lower yields. ${ }^{19-20,22-}$ ${ }^{24}$ This prompted us to develop a single step synthesis of $\mathrm{N}$-acyl anthranilamide and the quinazoline-4-one skeleton using isocyanide-insertion chemistry.

There are many reports about Pd-metal catalyzed aminocarbonylation for the synthesis of amides from 
aryl halides, ${ }^{26-30}$ however; the use and handling of toxic carbon monoxide limited the scope of this kind of reaction. In last few years, isocyanides which are isoelectronic with carbon monoxide have been used as synthetic surrogates of $\mathrm{CO}$ in $\mathrm{Pd}$-catalysed tandem reactions for synthesizing a broad range of nitrogencontaining heterocyles. ${ }^{31-32}$ Previously, we have been also engaged in exploring the applications of isocyanide as precursors and developed new methodologies for the synthesis of highly diverse nitrogen-containing heterocycles. ${ }^{33-34}$ In continuation of these studies, herein, we reported a synthetic protocol, enabled to furnish functionalized $\mathrm{N}$-acyl anthranilamide and quinazoline-4-one skeleton starting with o-halo substituted $\mathrm{N}$ phenylamide via a temperature dependent Pd-catalyzed cascade consisting of carboxamidation or carboxamidation/de-tertbutylation/cyclodehydration cascade.

\section{Yang et. al.}

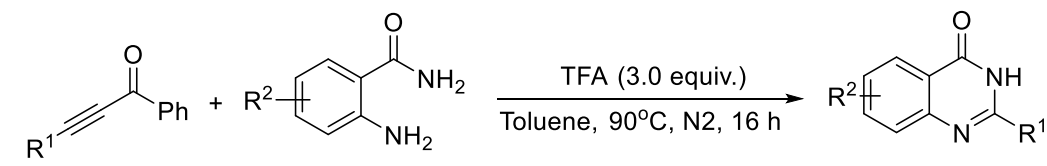

Shafiee et. al.

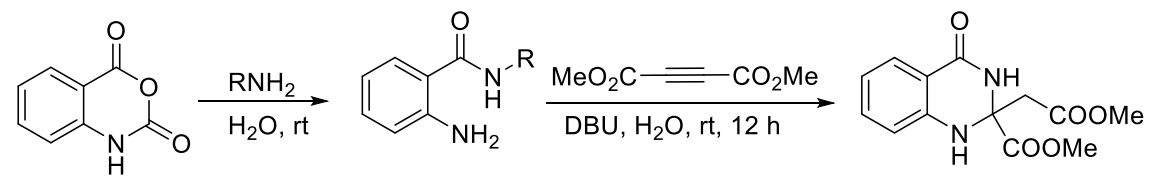

Ellman et. al.
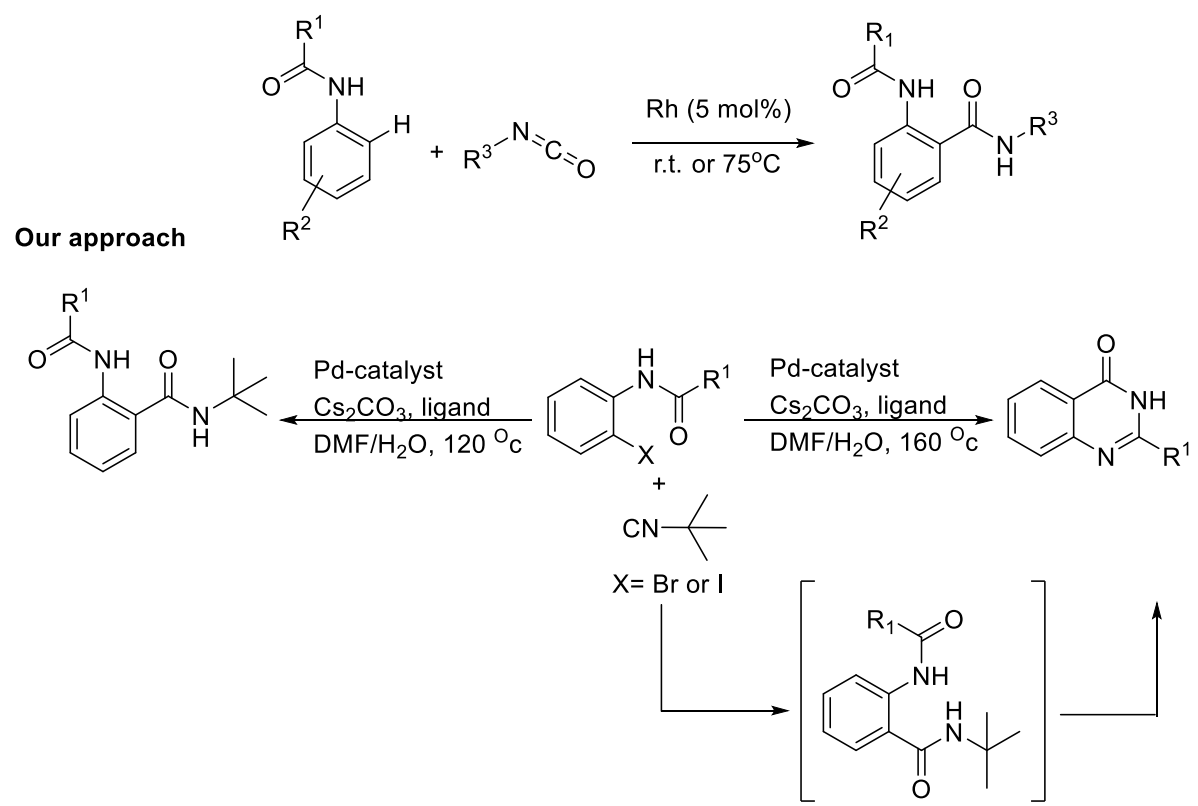

Scheme 1. Recent approaches for the synthesis of $\mathrm{N}$-acyl anthranilamide and quinazolin-4-one.

\section{Results and Discussion}

We initiated the study by using amide $\mathbf{1 a}$ and tert-butyl isocyanide $\mathbf{2} \mathbf{a}$ as a model substrates for the optimization of palladium-catalyzed carboxamidation reaction. The investigation was carried out using different catalysts, base and solvents (Table 1). The reaction did not proceed in the absence of the Pd catalyst 
(Table 1, entry 1). Among the three Pd-catalysts used $\left(\mathrm{PdCl}_{2}, \mathrm{Pd}(\mathrm{PPh})_{3}\right.$ and $\left.\mathrm{Pd}(\mathrm{OAc})_{2}\right), \mathrm{Pd}(\mathrm{OAc})_{2}$ was found to be the best and provided the product $3 a$ in $72 \%$ yield in $\mathrm{DMF} / \mathrm{H}_{2} \mathrm{O}$ as a solvent at $120{ }^{\circ} \mathrm{C}$ (Table 1 , entry 4). Furthermore, $\mathrm{PdCl}_{2}$ and $\mathrm{Pd}(\mathrm{PPh})_{3}$ furnished inferior yields of product 3a (Table 1, entry 2 and 3). We next tested the coupling reaction using various bases such as $\mathrm{Cs}_{2} \mathrm{CO}_{3}, \mathrm{~K}_{2} \mathrm{CO}_{3}, \mathrm{Na}_{2} \mathrm{CO}_{3}, \mathrm{~K}_{3} \mathrm{PO}_{4}$ and $\mathrm{KOtBu}$ in DMF/H $\mathrm{H}_{2} \mathrm{O}$ at $120{ }^{\circ} \mathrm{C}$, with $\mathrm{Pd}(\mathrm{OAc})_{2}$ as a catalyst, among these bases $\mathrm{Cs}_{2} \mathrm{CO}_{3}$ was found to be the most effective base (Table 1, entry 4). Using $\mathrm{Pd}(\mathrm{OAc})_{2}$ as catalyst and $\mathrm{Cs}_{2} \mathrm{CO}_{3}$ as base in $\mathrm{DMSO} / \mathrm{H}_{2} \mathrm{O}$ provided slightly poor yield of 3a (Table 1, entry 9), while using toluene and $\mathrm{CH}_{3} \mathrm{CN}$ under the same conditions furnished 3a in only poor yields (Table1, entry 10 and 11). The procedure was unfavourable when base was omitted from the reaction (Table 1, entry 12). Further optimization revealed that $\mathrm{PPh}_{3}$ was essential in this reaction as well. Without $\mathrm{PPh}_{3}$, the yield decreased to $49 \%$. When tested the carboxamidation reaction in dry DMF as solvent, the efficacy of carboxamidation reaction was affected and gave product only in trace amount (Table 1 , entry 13).

Table 1. Optimization of conditions for $\mathrm{N}$-acyl anthranilamide synthesis

\begin{tabular}{|c|c|c|c|c|}
\hline Entry & catalyst & base & ligand & $\underset{\text { b }}{\text { yield } \%}$ \\
\hline 1 & - & $\mathrm{Cs}_{2} \mathrm{CO}_{3}$ & $\mathrm{DMF} / \mathrm{H}_{2} \mathrm{O}$ & $0^{c}$ \\
\hline 2 & $\mathrm{PdCl}_{2}$ & $\mathrm{Cs}_{2} \mathrm{CO}_{3}$ & $\mathrm{DMF} / \mathrm{H}_{2} \mathrm{O}$ & 33 \\
\hline 3 & $\mathrm{Pd}(\mathrm{PPh} 3)_{4}$ & $\mathrm{Cs}_{2} \mathrm{CO}_{3}$ & $\mathrm{DMF} / \mathrm{H}_{2} \mathrm{O}$ & 59 \\
\hline 4 & $\mathrm{Pd}(\mathrm{OAc})_{2}$ & $\mathrm{Cs}_{2} \mathrm{CO}_{3}$ & $\mathrm{DMF} / \mathrm{H}_{2} \mathrm{O}$ & 72 \\
\hline 5 & $\mathrm{Pd}(\mathrm{OAc})_{2}$ & $\mathrm{~K}_{2} \mathrm{CO}_{3}$ & $\mathrm{DMF} / \mathrm{H}_{2} \mathrm{O}$ & 59 \\
\hline 6 & $\mathrm{Pd}(\mathrm{OAc})_{2}$ & $\mathrm{~K}_{3} \mathrm{PO}_{4}$ & $\mathrm{DMF} / \mathrm{H}_{2} \mathrm{O}$ & 41 \\
\hline 7 & $\mathrm{Pd}(\mathrm{OAc})_{2}$ & $\mathrm{KOtBu}$ & $\mathrm{DMF} / \mathrm{H}_{2} \mathrm{O}$ & 32 \\
\hline 8 & $\mathrm{Pd}(\mathrm{OAc})_{2}$ & $\mathrm{Na}_{2} \mathrm{CO}_{3}$ & $\mathrm{DMF} / \mathrm{H}_{2} \mathrm{O}$ & 53 \\
\hline 9 & $\mathrm{Pd}(\mathrm{OAc})_{2}$ & $\mathrm{Cs}_{2} \mathrm{CO}_{3}$ & $\mathrm{DMSO} / \mathrm{H}_{2} \mathrm{O}$ & 41 \\
\hline 10 & $\mathrm{Pd}(\mathrm{OAc})_{2}$ & $\mathrm{Cs}_{2} \mathrm{CO}_{3}$ & Toluene/ $\mathrm{H}_{2} \mathrm{O}$ & 19 \\
\hline 11 & $\mathrm{Pd}(\mathrm{OAc})_{2}$ & $\mathrm{Cs}_{2} \mathrm{CO}_{3}$ & $\mathrm{CH}_{3} \mathrm{CN} / \mathrm{H}_{2} \mathrm{O}$ & 31 \\
\hline 12 & $\mathrm{Pd}(\mathrm{OAc})_{2}$ & - & $\mathrm{DMF} / \mathrm{H}_{2} \mathrm{O}$ & $0^{d}$ \\
\hline 13 & $\mathrm{Pd}(\mathrm{OAc})_{2}$ & $\mathrm{Cs}_{2} \mathrm{CO}_{3}$ & DMF & trace \\
\hline
\end{tabular}

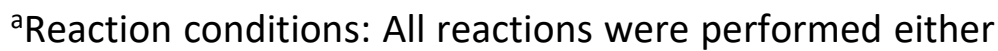
in microwave tube or $10 \mathrm{~mL}$ round bottom flask using $N$ (2-bromophenyl)benzamide 1 a (1.0 equiv.), $t$-butyl isocyanide $2 \mathrm{a}$ (1.1 equiv.), Pd-catalyst (5 mol \%), $\mathrm{PPh}_{3}(5$ $\mathrm{mol} \%$ ) and base (1.2 equiv.), solvent ( $0.5 \mathrm{~mL}$ of $\mathrm{H}_{2} \mathrm{O}$ in 1.5 $\mathrm{mL}$ of solvent) at $120^{\circ} \mathrm{C}$ for $15-20 \mathrm{~min}$ in $\mathrm{MW}$ or $4-5 \mathrm{hrs}$ at conventional heating. ${ }^{b}$ isolated yield. 
It is interesting to note that at room temprature there was no conversion but the reaction was completed within 15-20 min under MW conditions at $120^{\circ} \mathrm{C}$, while in the absence of MW irradiations it took 4$5 \mathrm{~h}$ to reach the completion. After having optimized reaction conditions for the carboxamidation of $\mathrm{N}$-(2bromophenyl)benzamide $\mathbf{1 a}$ with tert-butyl isocyanide $\mathbf{2 a}$, we further explore the reaction scope for other substituted $\mathrm{N}$-phenylamide with a range of isocyanides (Table 2 ). In addition to $t$-butyl isocyanide, the carboxamidation of 1a with tert-octyl and cyclohexyl isocyanide substrates provided $\mathrm{N}$-acyl anthranilamide products $3 \mathrm{~b}$ and $3 \mathrm{c}$ in good yields (63 and 74\%, respectively) when employing $5 \mathrm{~mol} \%$ of $\mathrm{Pd}(\mathrm{OAc})_{2}$ in $\mathrm{DMF} / \mathrm{H}_{2}$ Ounder microwave irraditation for $20 \mathrm{~min}$. Next, we investigated the scope of substituted $\mathrm{N}$-phenyl amide (Table 2). To our delight, many substituents at different positions on the phenyl group are compatible with the reaction conditions, producing the corresponding products in good yields (Table 2, entries $\mathbf{3 d - 3 i}$ ). For electron-donating group such as 3,4,5-trimethoxy, 4-methoxy or 2, 4-methyl substituted phenyl amide with tert-butyl or cyclohexyl isocyanides reactions work nicely and gave 58\%, 55\%, 59\% and 61\% yield respectively (Table 2, entry 3d-3g). Also, $m-\mathrm{Cl}$ and $p-\mathrm{F}$ on phenyl group were tolerated well and gave $61 \%$ and $59 \%$ yield respectively.

Table 2. Substrate scope of Pd-catalyzed cascade for the synthesis of diverse $\mathrm{N}$-acyl anthranilamide derivative ${ }^{\mathrm{a}}$

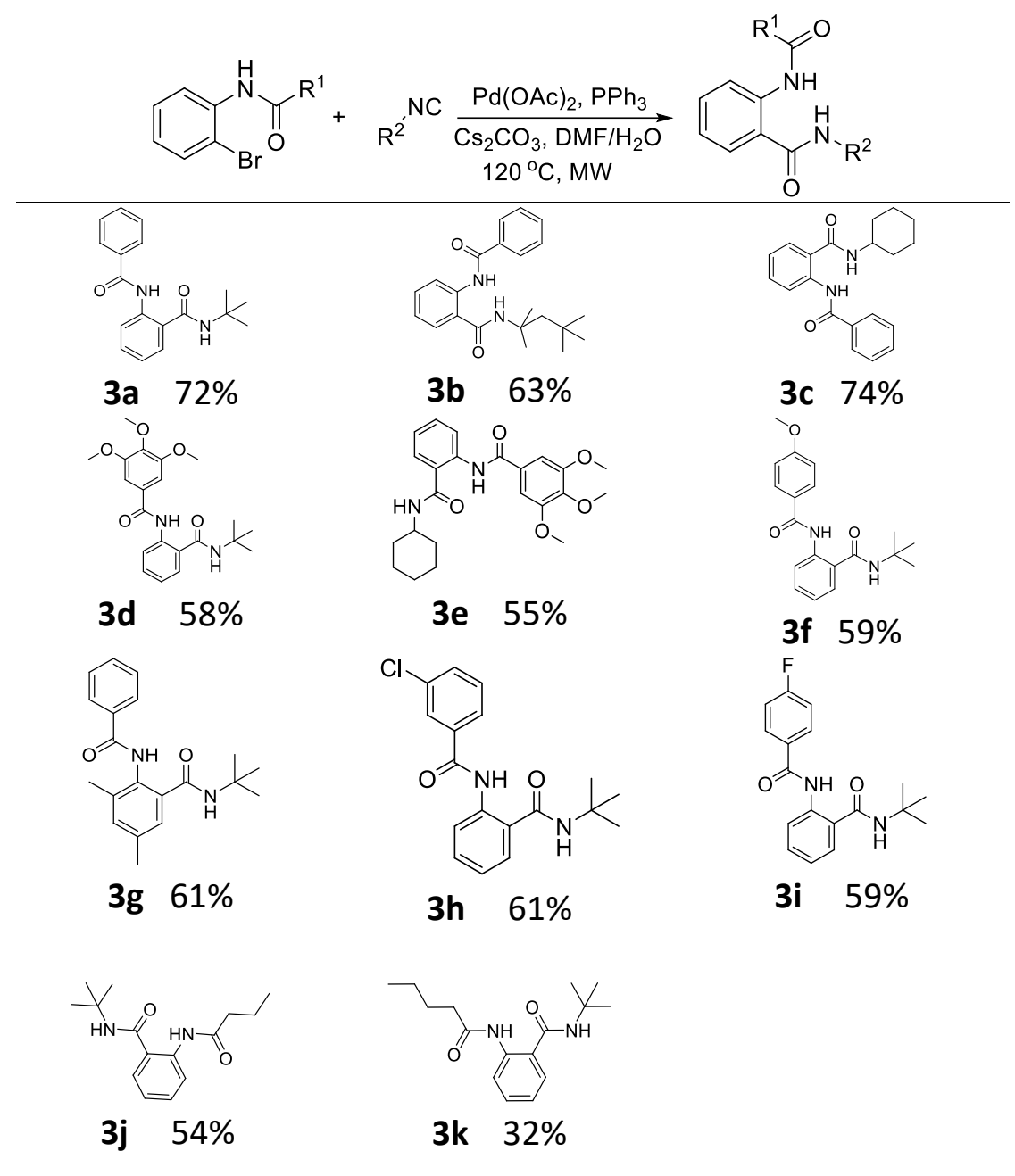

Reaction conditions: $\mathrm{Pd}(\mathrm{OAc})_{2}$ (5 mol \%), $\mathrm{Cs}_{2} \mathrm{CO}_{3}$ (1.2 equiv.), $\mathrm{DMF} / \mathrm{H}_{2} \mathrm{O}(2 \mathrm{~mL}), \mathrm{MW}, 120{ }^{\circ} \mathrm{C}$, reaction time $20 \mathrm{~min}$. bYields refer to isolated products. 
(Table 2, entry $\mathbf{3 h} \mathbf{8 3 i}$ ). Moreover, we investigated $N$-phenylamide bearing an alkyl group such as $t$-butyl and $\mathrm{n}$-propyl instead of phenyl group and the reaction gave corrosponding products in decent yield (Table 2, entry 3j-3n), however slightly lower yield obtained compared to phenyl group.

There are few methods available for synthesizing quinazolin-4-one by the cyclodehydration reaction of $\mathrm{N}$-acyl anthranilamides. Although, we envisaged that by conducting the Pd-catalyzed reaction at elevated temperature, both the carboxamidation and cyclodehydration sequence could be accomplished in a single step. To synthesize quinazolin-4-one selectively, we did temperature variations under previously optimized conditions (Table 3). Increasing the temperature of the reaction between $\mathbf{1 a}$ and $\mathbf{2 a}$ under the optimized catalyst conditions to $140^{\circ} \mathrm{C}$ and monitoring the reaction by ${ }^{1} \mathrm{H} \mathrm{NMR,} \mathrm{N}$-acyl anthranilamide product $3 a$ was formed in $42 \%$ yield along with the quinazoline-4-one (4a) in $21 \%$ yield (Table 3 , entry 3 ). When we elevated the temprature upto $160^{\circ} \mathrm{C}$, quinazoline-4-one was formed selectively (Table 3, entry 5). Also, we found that in the absence of Pd-catalyst, heating the isolated $\mathrm{N}$-acyl anthranilamide 3a gave quinazoline-4-one $4 \mathrm{a}$ only in trace amount. This result suggested to us that cyclodehydration of $\mathbf{3 a}$ to $\mathbf{4 a}$ is assisted by the $\mathbf{P d}$ - catalyst rather than being solely thermally induced.

Table 3. Optimization of condition for quinazolinone synthesis ${ }^{\mathrm{a}}$

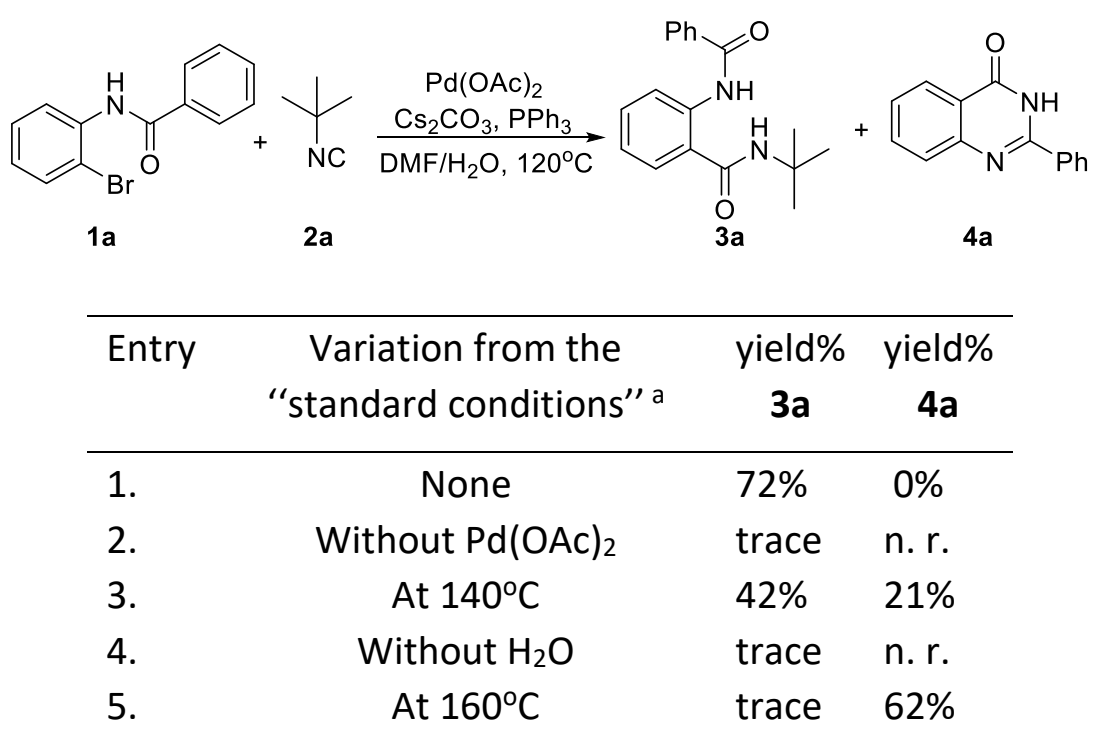

${ }^{a}$ Reaction conditions: reactions were performed in a microwave vial using $\mathrm{N}$-(2-bromophenyl)benzamide 1a (1.0 equiv.), $t$-butylisocyanide 2 a (1.1 equiv.),Pd-catalyst ( $5 \mathrm{~mol} \%$ ), $\mathrm{PPh}_{3}\left(5 \mathrm{~mol} \%\right.$ ) and $\mathrm{CS}_{2} \mathrm{CO}_{3}$ (1.2 equiv.), solvent ( $0.5 \mathrm{~mL}$ of $\mathrm{H}_{2} \mathrm{O}$ in $1.5 \mathrm{~mL}$ DMF) at different temperatures for 15-20 min in MW, yields refer to isolated products.

After optimizing the reaction conditions for the selective synthesis of quinazoline-4-one by the reaction of $\mathbf{1 a}$ with $\mathbf{2 a}$, we investigated the scope of one step cascade reaction for a broad range of $\mathrm{N}$-phenylamides. $\mathrm{A}$ number of substituents at different positions on the phenyl group such alkyl, methoxy and phenyl compatible

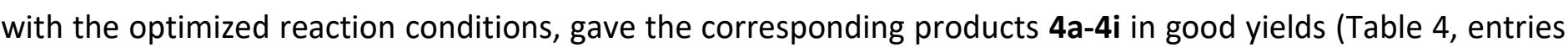
4a-4i). Furthermore, when we tested cyclohexyl isocyanide in place of $t$-butyl isocyanide, no quinazoline-4-one 
formed, $\mathrm{N}$-acyl anthranilamide was the product. Also, this experiment indirectly supports de-tert-butylation (step viii, scheme 2) during the synthesis of quinazoline-4-one.

Table 4. Substrate scope of Pd-catalyzed cascade for synthesis of diverse quinazolinone derivatives ${ }^{\text {a }}$

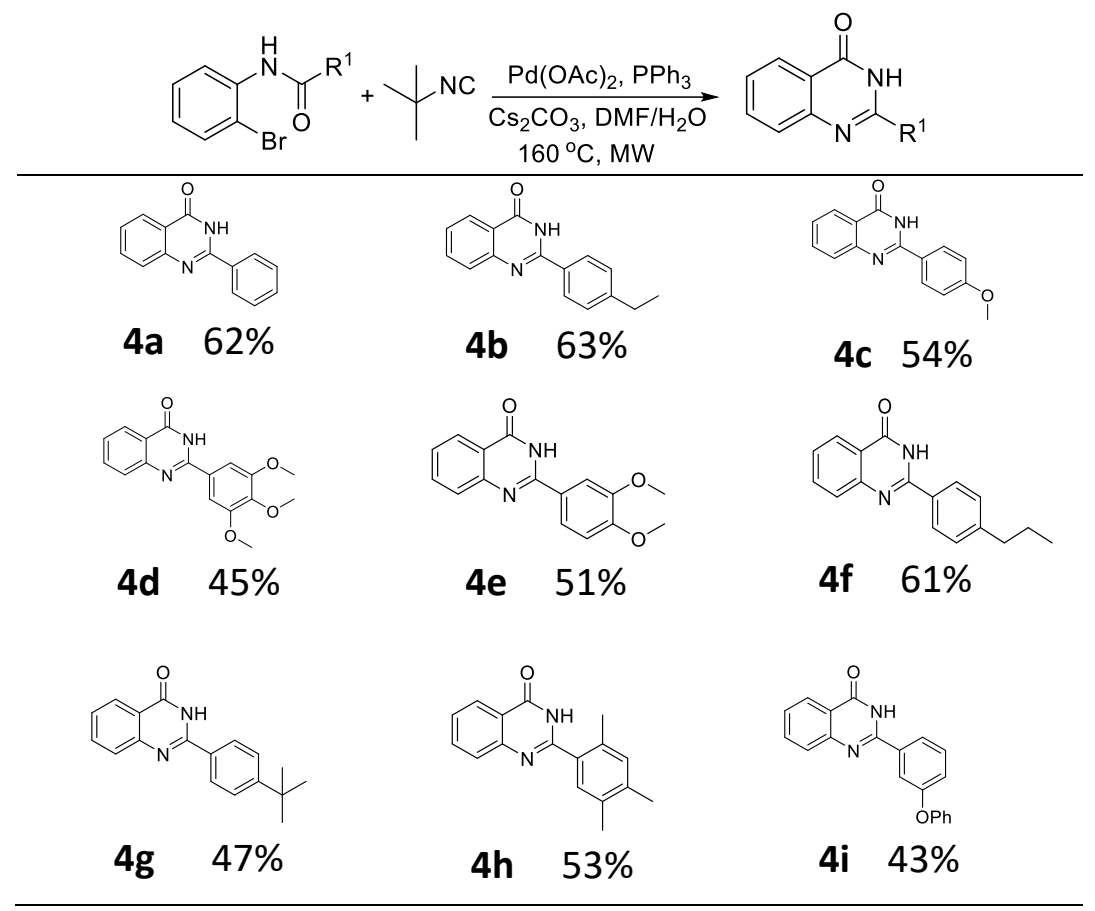

\begin{abstract}
aReaction conditions: $\mathrm{Pd}(\mathrm{OAc})_{2}(5 \mathrm{~mol} \%), \mathrm{Cs}_{2} \mathrm{CO}_{3}$ (1.2 equiv.), $\mathrm{DMF} / \mathrm{H}_{2} \mathrm{O}(1.7 \mathrm{~mL}), \mathrm{MW}, 160{ }^{\circ} \mathrm{C}$, reaction time $20 \mathrm{~min}$. Yields refer to isolated products.
\end{abstract}

A plausible mechanism for anthranilamide and quinazolinone synthesis is proposed in Scheme 2. Thus, oxidative insertion of $\mathrm{Pd}(0)$ into the o-halo substituted $\mathrm{N}$-phenylamide (i) leads to the intermediate (ii) which on insertion of $t$-butyl isocyanide (2a) leads to $\mathrm{Pd}$ (II) species (iii), Intermediate (iii) via fast ligand exchange with water gives intermediate (iv), which can react through two differnet pathways which depend on reaction temperature. At lower temperature $\left(120^{\circ} \mathrm{C}\right)$ pathway $A$ is followed, reductive elimination and subsequent tautomerization, to give $\mathrm{N}$-acyl anthranilamide as product and $\mathrm{Pd}(0)$ for another catalytic cycle. At higher temperature $\left(160^{\circ} \mathrm{C}\right)$ reaction follows path $\mathrm{B}$, which goes through de-tertbutylation and subsequent cyclodehydration in the persence of $\mathrm{Pd}$-catalyst to furnish quinazoline product. 


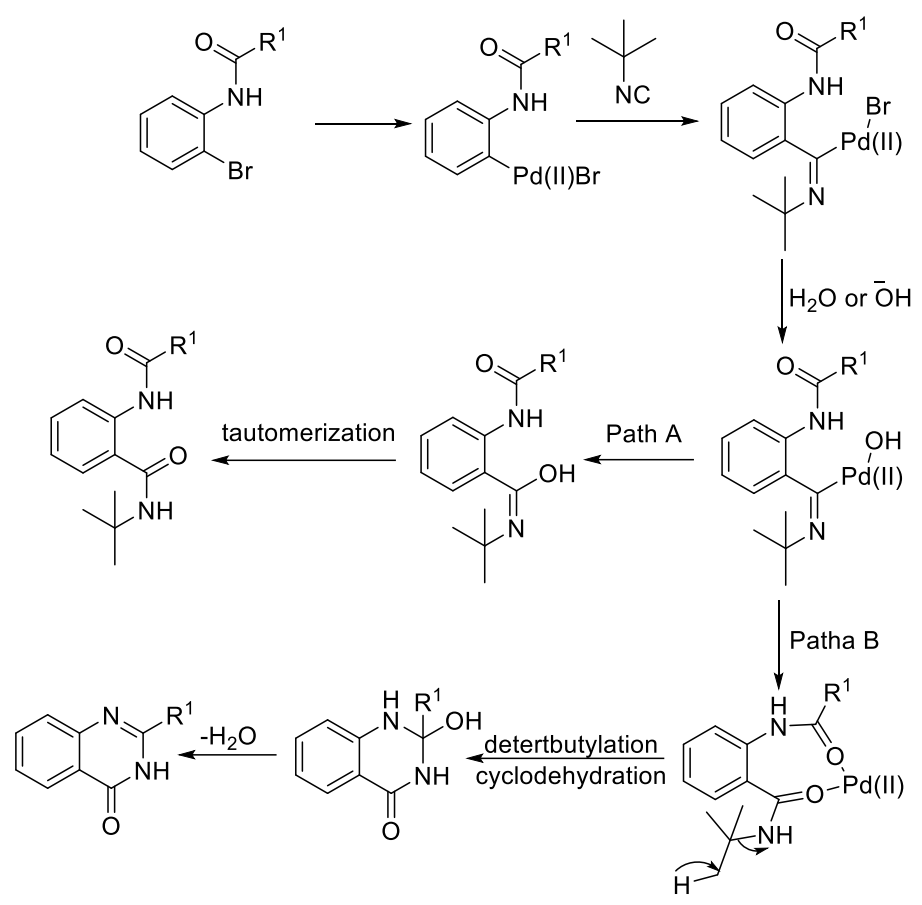

Scheme 2. Plausible mechanism for anthranilamide and quinazolinone synthesis.

\section{Conclusions}

In summary, we have reported the first synthesis of $\mathrm{N}$-acyl anthranilamide and quinazolin-4-one derivatives via Pd-catalyzed cascade reaction consisting of isocyanide insertion into diverse o-halo substituted $\mathrm{N}$-phenylamides. This cascade reaction allows the synthesis of $\mathrm{N}$-acyl anthranilamide at $120^{\circ} \mathrm{C}$ by use of easily available and less expensive starting materials, while at elevated temperature $\left(160^{\circ} \mathrm{C}\right)$ provides quinazolin-4-one as the only detectable product. Additionally, a broad range of substrates are tolerated in this protocol which provides a diverse library of $\mathrm{N}$-acyl anthranilamide and quinazolin-4-one derivatives for combinatorial and medicinal chemistry use. Moreover, reported work here contributes to expand the growing number of transition metal catalysed sequential reactions in one-pot for the synthesis of functionalized nitrogen-containing heterocycles.

\section{Experimental Section}

General. All reagents and solvents were purchased from commercial sources and used without purification. NMR spectra were recorded on a Bruker spectrometer at 300 (400) and 75 (100) MHz, respectively in deuterated solvents with TMS as internal reference (chemical shifts $\delta$ in ppm, coupling constant $J$ in $\mathrm{Hz}$.). Multiplicities are reported as follows: singlet (s), doublet (d), triplet (t), multiplet (m), and broad singlet (brs). Mass spectra and HRMS were taken in the ESI positive ion mode. The reaction progress was monitored by thin layer chromatography (TLC) on pre-coated silica gel plates. Column chromatography was performed over Merck silica gel (230-400 flash). All compounds were characterized by TLC, ${ }^{1} \mathrm{H}$ NMR and ${ }^{13} \mathrm{C}$ NMR and HRMS. 
General procedure for the synthesis of substituted $\mathbf{N}$-acyl anthranilamides(3a-3k). Substituted Nphenylamide 1 (1 equiv.), isocyanide 2 (1.1 equiv.), $\mathrm{Pd}(\mathrm{OAc})_{2}(5 \mathrm{~mol} \%), \mathrm{Cs}_{2} \mathrm{CO}_{3}$ (1.2 equiv.), $\mathrm{PPh}_{3}(5 \mathrm{~mol} \%)$ and DMF: $\mathrm{H}_{2} \mathrm{O}(3: 1)$ as a solvent were added in a $10 \mathrm{~mL}$ microwave vial containing a stirring bar, the vial was sealed tightly with a Teflon cap and placed in microwave cavity for 15-20 min at a pre-selected temperature of 120 ${ }^{\circ} \mathrm{C}$. After completion of the reaction as indicated by TLC, the resulting mixture was filtered through a pad of celite, and the celite was rinsed with EtOAc. The solvent was evaporated under reduced pressure and the residue was purified by flash column chromatography on silica gel (eluent: hexane/ EtOAc) affording the corresponding coupling product 3a-3kin $74-32 \%$ yields.

General procedure for the synthesis of substituted quinazoline-4-one (4a-4i). Substituted N-phenylamide 1 (1 equiv.), isocyanide 2 (1.1 equiv.), $\mathrm{Pd}(\mathrm{OAc})_{2}(5 \mathrm{~mol} \%), \mathrm{Cs}_{2} \mathrm{CO}_{3}\left(1.2\right.$ equiv.), $\mathrm{PPh}_{3}\left(5 \mathrm{~mol} \%\right.$ ) and DMF: $\mathrm{H}_{2} \mathrm{O}(3: 1)$ as a solvent were added in a $10 \mathrm{~mL}$ microwave vial containing a stirring bar, the vial was sealed tightly with a Teflon cap and placed in a microwave cavity for $15-20 \mathrm{~min}$ at a pre-selected temperature of $160{ }^{\circ} \mathrm{C}$. After completion of the reaction as indicated by TLC, the resulting mixture was filtered through a pad of celite, and the celite was rinsed with EtOAc. The solvent was evaporated under reduced pressure and the residue was purified by flash column chromatography on silica gel (eluent: hexane/ EtOAc) affording the corresponding coupling products $4 a-4 i$ in $63-43 \%$ yields.

2-Benzamido-N-tert-butylbenzamide (3a). Solid, Yield 72\%,mp 143-146 ${ }^{\circ} \mathrm{C}, \mathrm{FT}-\mathrm{IR}(\mathrm{KBr}) \vee\left(\mathrm{cm}^{-1}\right): 3425,2946$, 2324, 1627, 1106, 759, ${ }^{1} \mathrm{H}$ NMR (400 MHz, CDCl 3 ): $\delta 11.95$ (brs, 1H), 8.77 (d, J $\left.8.4 \mathrm{~Hz}, 1 \mathrm{H}\right), 8.06-8.04(\mathrm{~m}, 2 \mathrm{H})$, 7.58-7.44 (m, 5H), 7.09 (t, J $7.2 \mathrm{~Hz}, 1 \mathrm{H}), 6.16$ (br s, 1H), $1.52(\mathrm{~s}, 9 \mathrm{H}) \mathrm{ppm},{ }^{13} \mathrm{C} \mathrm{NMR}\left(100 \mathrm{MHz}, \mathrm{CDCl}_{3}\right): 169.0$, 165.5, 139.5, 134.8, 132.2, 131.7, 128.7, 127.4, 126.4, 122.7, 122.3, 121.6, 52.2, 28.7 ppm, HRMS (ESI) Calcd. for $\mathrm{C}_{18} \mathrm{H}_{20} \mathrm{~N}_{2} \mathrm{O}_{2}[\mathrm{M}+\mathrm{H}]^{+} 297.1525$ Found 297.1595.

2-Benzamido- $\mathbf{N}$-(2,4,4-trimethylpentan-2-yl)benzamide (3b). Solid, Yield $63 \%,{ }^{1} \mathrm{H} N M R\left(400 \mathrm{MHz} \mathrm{CDCl}_{3}\right): \delta$ 11.9 (brs, 1H), 8.76 (d, J $8.0 \mathrm{~Hz}, 1 \mathrm{H}), 8.05(\mathrm{~d}, J 6.8 \mathrm{~Hz}, 2 \mathrm{H}), 7.58-7.42(\mathrm{~m}, 5 \mathrm{H}), 7.08(\mathrm{t}, J 7.2 \mathrm{~Hz}, 1 \mathrm{H}), 6.20$ (brs, $1 \mathrm{H}), 1.92(\mathrm{~s}, 2 \mathrm{H}), 1.57(\mathrm{~s}, 6 \mathrm{H}), 1.07$ (s, 9H) ppm, ${ }^{13} \mathrm{C} N M R\left(100 \mathrm{MHz}, \mathrm{CDCl}_{3}\right): 168.8,165.4,139.3,134.8,132.0$, 131.7, 128.7, 127.3, 126.3, 122.8, 122.7, 121.7, 56.1, 51.5, 31.7, 31.5, 29.1 ppm, HRMS (ESI) Calcd. for $\mathrm{C}_{22} \mathrm{H}_{28} \mathrm{~N}_{2} \mathrm{O}_{2}[\mathrm{M}+\mathrm{H}]^{+}$353.2151 Found 353.2221.

2-Benzamido- $N$-cyclohexylbenzamide (3c). Solid, Yield 74\%, ${ }^{1} \mathrm{H}$ NMR (300 MHz, $\left.\mathrm{CDCl}_{3}\right): \delta 12.0$ (brs, $\left.1 \mathrm{H}\right), 8.77$ (d, J $8.1 \mathrm{~Hz}, 1 \mathrm{H}), 8.05(\mathrm{~d}, J 5.7 \mathrm{~Hz}, 2 \mathrm{H}), 7.55-7.49(\mathrm{~m}, 5 \mathrm{H}), 7.05(\mathrm{t}, J 7.2 \mathrm{~Hz}, 1 \mathrm{H}), 6.43(\mathrm{brs}, 1 \mathrm{H}), 4.00-3.97(\mathrm{~m}, 1 \mathrm{H})$, 2.07-2.04 (m, 2H), 1.81-1.67 (m, 3H), 1.51-1.21 (m, 5H) ppm, ${ }^{13} \mathrm{C} \mathrm{NMR}\left(75 \mathrm{MHz}, \mathrm{CDCl}_{3}\right): 168.3,165.5,139.7$, 134.8, 132.4, 131.8, 128.7, 127.3, 126.6, 122.7, 121.5, 121.0, 48.8, 33.0, 25.4, 24.9 ppm, HRMS (ESI) Calcd. for $\mathrm{C}_{20} \mathrm{H}_{22} \mathrm{~N}_{2} \mathrm{O}_{2}[\mathrm{M}+\mathrm{H}]^{+} 323.1681$ Found 323.1751

$\mathbf{N}$-(2-(tert-Butylcarbamoyl)phenyl)-3,4,5-trimethoxybenzamide (3d). Solid, Yield 58\%, ${ }^{1} \mathrm{H} \mathrm{NMR}(400 \mathrm{MHz}$, $\mathrm{CDCl}_{3}$ ): $\delta 12.1$ (brs, $\left.1 \mathrm{H}\right), 8.79(\mathrm{~d}, J$ 8.4, $1 \mathrm{H}), 7.51-7.43(\mathrm{~m}, 2 \mathrm{H}), 7.32(\mathrm{~s}, 2 \mathrm{H}), 7.08(\mathrm{t}, J 7.6 \mathrm{~Hz}, 1 \mathrm{H}), 6.13(\mathrm{brs}, 1 \mathrm{H})$, 3.97 (s, 6H), 3.92 (s, 3H), 1.49 (s, 9H) ppm, $\left.{ }^{13} \mathrm{C} \mathrm{NMR} \mathrm{(100} \mathrm{MHz,} \mathrm{CDCl} 3\right): 169.3,165.2,153.3,141.2,140.1,132.6$, 130.4, 126.6, 122.8, 121.7, 121.4, 104.8, 61.1, 56.3, 52.4, 28.9 ppm, HRMS (ESI) Calcd. for $\mathrm{C}_{21} \mathrm{H}_{26} \mathrm{~N}_{2} \mathrm{O}_{5}[\mathrm{M}+\mathrm{H}]^{+}$ 387.1842 Found 387.1917.

$\mathbf{N}$-(2-(Cyclohexylcarbamoyl)phenyl)-3,4,5-trimethoxybenzamide (3e). Solid, Yield 55\%, ${ }^{1} \mathrm{H} \mathrm{NMR}(300 \mathrm{MHz}$, $\left.\mathrm{CDCl}_{3}\right): \delta 12.1$ (brs, $\left.1 \mathrm{H}\right), 8.88-8.47(\mathrm{~m}, 1 \mathrm{H}), 7.54-7.48(\mathrm{~m}, 2 \mathrm{H}), 7.30(\mathrm{~s}, 2 \mathrm{H}), 7.11(\mathrm{t}, J 9.6 \mathrm{~Hz}, 1 \mathrm{H}), 6.28(\mathrm{brs}, 1 \mathrm{H})$, $3.98(\mathrm{~s}, 6 \mathrm{H}), 3.93(\mathrm{~s}, 3 \mathrm{H}), 3.98-3.93(\mathrm{~m}, 1 \mathrm{H}), 2.05-2.02(\mathrm{~m}, 2 \mathrm{H}), 1.80-1.66(\mathrm{~m}, 3 \mathrm{H}), 1.49-1.20(\mathrm{~m}, 5 \mathrm{H}) \mathrm{ppm},{ }^{13} \mathrm{C}$ NMR $\left(75 \mathrm{MHz}_{\mathrm{CDCl}}\right)$ : 168.3, 165.2, 153.2, 141.0, 139.8, 132.5, 130.3, 126.4, 122.7, 121.3, 120.9, 104.7, 60.9, 56.2, 48.8, 32.9, 25.4, 24.8 ppm, HRMS (ESI) Calcd. for $\mathrm{C}_{23} \mathrm{H}_{28} \mathrm{~N}_{2} \mathrm{O}_{5}[\mathrm{M}+\mathrm{H}]^{+} 413.1998$ Found 413.2073.

N-tert-Butyl-2-(4-methoxybenzamido)benzamide (3f). Solid, Yield 59\%, ${ }^{1} \mathrm{H} N M R\left(400 \mathrm{MHz}, \mathrm{CDCl}_{3}\right): \delta 11.78$ (brs, 1H), 8.69 (d, J 8.4 Hz, 1H), 7.98 (d, J 8.8 Hz, 2H), 7.44-7.39 (m, 2H), 7.00-6.94 (m, 3H), 6.29 (brs, $1 \mathrm{H}), 3.86$ 
(s, 3H), 1.50 (s, 9H) ppm, ${ }^{13} \mathrm{C}$ NMR (100 MHz, CDCl $): 169.3,165.2,162.6,139.7,132.2,129.4,127.4,126.8$, 122.6, 122.4, 121.6, 114.1, 55.6, 52.3, 28.7 ppm, HRMS (ESI) Calcd. for $\mathrm{C}_{19} \mathrm{H}_{22} \mathrm{~N}_{2} \mathrm{O}_{3}[\mathrm{M}+\mathrm{H}]^{+} 327.1630$ Found 327.1705 .

2-Benzamido-N-tert-butyl-3,5-dimethylbenzamide (3g). Solid, Yield 61\%, ${ }^{1} \mathrm{H}$ NMR $\left(400 \mathrm{MHz}, \mathrm{CDCl}_{3}\right): \delta 9.88$ (brs, 1H), $8.16(\mathrm{~d}, J 7.5 \mathrm{~Hz}, 2 \mathrm{H}), 7.58-7.46(\mathrm{~m}, 3 \mathrm{H}), 7.00(\mathrm{~s}, 1 \mathrm{H}), 6.95(\mathrm{~s}, 1 \mathrm{H}), 6.50$ (brs, 1H), $2.25(\mathrm{~s}, 3 \mathrm{H}), 2.19$ (s, $3 \mathrm{H}), 1.25$ (s, 9H) ppm, ${ }^{13} \mathrm{C} \mathrm{NMR}\left(100 \mathrm{MHz} \mathrm{CDCl}_{3}\right):$ 169.2, 167.4, 136.6, 136.5, 135.4, 133.8, 132.6, 131.7, 130.3, 128.4, 127.8, 125.3, 51.6, 28.4, 20.8, 18.4 ppm, HRMS (ESI) Calcd. for $\mathrm{C}_{20} \mathrm{H}_{24} \mathrm{~N}_{2} \mathrm{O}_{2}[\mathrm{M}+\mathrm{H}]^{+} 325.1838$ Found 325.1912.

N-tert-Butyl-2-(3-chlorobenzamido)benzamide (3h). Solid, Yield 61\%, ${ }^{1} \mathrm{H}$ NMR $\left(400 \mathrm{MHz}, \mathrm{CDCl}_{3}\right): \delta 12.0$ (s, $1 \mathrm{H}), 8.69(\mathrm{~s}, J 8.4 \mathrm{~Hz}, 1 \mathrm{H}), 8.03(\mathrm{~s}, 1 \mathrm{H}), 7.87(\mathrm{~d}, J 7.6 \mathrm{~Hz}, 1 \mathrm{H}), 7.53-7.42(\mathrm{~m}, 4 \mathrm{H}), 7.04(\mathrm{t}, J 7.6 \mathrm{~Hz}, 1 \mathrm{H}), 6.33(\mathrm{br} \mathrm{s}$, 1H), $1.53(\mathrm{~s}, 9 \mathrm{H}) \mathrm{ppm},{ }^{13} \mathrm{C} \mathrm{NMR}\left(100 \mathrm{MHz}_{\mathrm{CDCl}}\right)$ : 169.2, 164.3, 139.3, 136.9, 135.1, 132.3, 131.9, 130.2, 128.3, 126.8, 125.2, 123.2, 122.4, 121.7, 52.4, 28.9 ppm, HRMS (ESI) Calcd. for $\mathrm{C}_{18} \mathrm{H}_{19} \mathrm{CIN}_{2} \mathrm{O}_{2}[\mathrm{M}+\mathrm{H}]^{+} 331.1135$ Found 331.1212 .

N-tert-Butyl-2-(4-fluorobenzamido)benzamide (3i). Solid, Yield 59\%, $\left.{ }^{1} \mathrm{H} \mathrm{NMR} \mathrm{(400} \mathrm{MHz,} \mathrm{CDCl}_{3}\right): \delta 11.9$ (brs, $1 \mathrm{H}), 8.72(\mathrm{~d}, J$ 8.4, $1 \mathrm{H}), 8.05-8.02(\mathrm{~m}, 2 \mathrm{H}), 7.49-7.42(\mathrm{~m}, 2 \mathrm{H}), 7.20(\mathrm{t}, J 8.4 \mathrm{~Hz}, 2 \mathrm{H}), 7.06(\mathrm{t}, J 7.6 \mathrm{~Hz}, 1 \mathrm{H}), 6.19$ (brs, 1H), 1.50 (s, 9H) ppm, ${ }^{13} \mathrm{C}$ NMR (100 MHz, CDCl 3$): 169.2,164.5,139.7,132.4,131.3,131.2,130.0,129.9$, 126.7, 123.0, 122.2, 121.7, 116.0, 115.8, 52.4, 28.9 ppm, HRMS (ESI) Calcd. for $\mathrm{C}_{18} \mathrm{H}_{19} \mathrm{FN}_{2} \mathrm{O}_{2}[\mathrm{M}+\mathrm{H}]^{+} 315.1431$ Found 315.1506.

N-tert-Butyl-2-butyramidobenzamide (3k). Solid, Yield 54\%, ${ }^{1} \mathrm{H}$ NMR (400 MHz, $\left.\mathrm{CDCl}_{3}\right): 10.8$ (brs, $\left.1 \mathrm{H}\right), 8.4$ (s, 1H), $7.39(\mathrm{t}, J 5.4 \mathrm{~Hz}, 2 \mathrm{H}), 7.00(\mathrm{~s}, J 5.4 \mathrm{~Hz}, 1 \mathrm{H}), 6.16$ (brs, 1H), $2.35(\mathrm{t}, J 7.2 \mathrm{~Hz}, 2 \mathrm{H}), 1.76(\mathrm{t}, J 7.2 \mathrm{~Hz}, 2 \mathrm{H}), 1.45$ $(\mathrm{s}, 9 \mathrm{H}), 1.02-0.96(\mathrm{~m}, 3 \mathrm{H}) \mathrm{ppm},{ }^{13} \mathrm{C} \mathrm{NMR}\left(75 \mathrm{MHz}^{\mathrm{CDCl}}\right)_{3}: 172.1,169.0,139.2,132.1,126.7,122.6,122.4$, 121.7, 52.2, 40.5, 28.9, 19.2, 13.9 ppm, HRMS (ESI) Calcd. for $\mathrm{C}_{15} \mathrm{H}_{22} \mathrm{~N}_{2} \mathrm{O}_{2}[\mathrm{M}+\mathrm{H}]^{+}$263.1681 Found 263.1757.

N-tert-Butyl-2-pentanamidobenzamide (3j). Solid, Yield $=78 \%,{ }^{1} \mathrm{H} \mathrm{NMR}\left(400 \mathrm{MHz}^{\mathrm{CDCl}} 3\right.$ ): 10.8 (brs, $\left.1 \mathrm{H}\right), 8.52$ (d, J 8.4 Hz, 1H), 7.51-7.36 (m, 2H), $7.03(\mathrm{t}, J 7.6 \mathrm{~Hz}, 1 \mathrm{H}), 6.16$ (brs, 1H), 2.40 (t, J 7.6 Hz, 2H), 1.76-1.64 (m, 2H), $1.48(\mathrm{~s}, 9 \mathrm{H}), 1.45-1.36(\mathrm{~m}, 2 \mathrm{H}), 0.97(\mathrm{t}, \mathrm{J} 7.6 \mathrm{~Hz}, 3 \mathrm{H}) \mathrm{ppm},{ }^{13} \mathrm{C} \mathrm{NMR}\left(75 \mathrm{MHz}, \mathrm{CDCl}_{3}\right): 172.1,168.8,139.1,131.9$, 126.4, 122.4, 122.2, 121.5, 52.0, 38.1, 28.7, 27.6, 22.3, 13.7 ppm, HRMS (ESI) Calcd. for $\mathrm{C}_{16} \mathrm{H}_{24} \mathrm{~N}_{2} \mathrm{O}_{2}[\mathrm{M}+\mathrm{H}]^{+}$ 277.1838 Found 277.1904.

2-Phenylquinazolin-4(3H)-one (4a). Solid, Yield $=62 \%, \mathrm{mp} 176-178{ }^{\circ} \mathrm{C}$ FT-IR $(\mathrm{KBr}) v\left(\mathrm{~cm}^{-1}\right): 3425,2943,2354$, 1637, 1123, 761, ${ }^{1} \mathrm{H}$ NMR (400 MHz, DMSO-d 6 ): 12.5 (brs, 1H), 8.20 (t, J $\left.8.4 \mathrm{~Hz}, 3 \mathrm{H}\right), 7.86(\mathrm{t}, J 7.6 \mathrm{~Hz}, 1 \mathrm{H}), 7.76$ $(d, J 8.0 \mathrm{~Hz}, 1 \mathrm{H}), 7.59-7.50(\mathrm{~m}, 4 \mathrm{H}) \mathrm{ppm},{ }^{13} \mathrm{C} N M R\left(100 \mathrm{MHz}, \mathrm{DMSO}-\mathrm{d}_{6}\right): 162.7,152.7,149.2,135.0,133.1$, $131.8,129.0,128.2,127.9,127.0,126.3,121.4$ ppm, HRMS (ESI) Calcd. for $\mathrm{C}_{14} \mathrm{H}_{10} \mathrm{~N}_{2} \mathrm{O}[\mathrm{M}+\mathrm{H}]^{+} 223.0793$ Found 223.0864.

2-(4-Ethylphenyl)quinazolin-4(3H)-one(4b). Solid, Yield 63\%, ${ }^{1} \mathrm{H}$ NMR (300 MHz, CDCl $): \delta 11.5$ (brs, $\left.1 \mathrm{H}\right), 8.36$ $(\mathrm{d}, J=5.8 \mathrm{~Hz}, 1 \mathrm{H}), 8.21(\mathrm{~d}, J 6.0 \mathrm{~Hz}, 2 \mathrm{H}), 7.86-7.79(\mathrm{~m}, 2 \mathrm{H}), 7.53-7.51(\mathrm{t}, J 5.1 \mathrm{~Hz}, 1 \mathrm{H}), 7.50(\mathrm{~d}, J 6.0 \mathrm{~Hz}, 2 \mathrm{H}), 2.81$ (q, J $5.7 \mathrm{~Hz}, 2 \mathrm{H}), 1.35$ (t,J $5.7 \mathrm{~Hz}, 3 \mathrm{H}) \mathrm{ppm},{ }^{13} \mathrm{C} \mathrm{NMR}\left(75 \mathrm{MHz}, \mathrm{CDCl}_{3}\right): \delta$ 163.7, 151.7, 149.6, 148.4, 134.8, 130.2, $128.6,127.9,127.4,126.5,126.4,28.8,15.3$ ppm.

2-(4-Methoxyphenyl)quinazolin-4(3H)-one (4c). Solid, Yield 54\%, ${ }^{1} \mathrm{H} N M R\left(400 \mathrm{MHz}, \mathrm{DMSO}-\mathrm{d}_{6}\right): \delta 12.4$ (brs, $1 \mathrm{H}), 8.21-8.13(\mathrm{~m}, 3 \mathrm{H}), 7.84(\mathrm{t}, J=8.4 \mathrm{~Hz}, 1 \mathrm{H}), 7.72(\mathrm{~d}, J=8.0 \mathrm{~Hz}, 1 \mathrm{H}), 7.51(\mathrm{t}, J=8.0 \mathrm{~Hz}, 1 \mathrm{H}), 7.10(\mathrm{~d}, J=8.8 \mathrm{~Hz}, 2 \mathrm{H})$, $3.88(\mathrm{~s}, 3 \mathrm{H}) \mathrm{ppm},{ }^{13} \mathrm{C}$ NMR $\left(100 \mathrm{MHz}, \mathrm{DMSO}-\mathrm{d}_{6}\right): \delta 162.3,161.8,151.8,148.9,134.5,129.4,127.3,126.1$, 125.7, 124.7, 120.7, 113.9, 55.4 ppm, HRMS (ESI) Calcd. for $\mathrm{C}_{15} \mathrm{H}_{12} \mathrm{~N}_{2} \mathrm{O}_{2}[\mathrm{M}+\mathrm{H}]^{+} 253.0899$ Found 253.0970.

2-(3,4,5-Trimethoxyphenyl)quinazolin-4(3H)-one (4d). Solid, Yield 45\%, ${ }^{1} \mathrm{H} N M R\left(400 \mathrm{MHz}, \mathrm{DMSO}-\mathrm{d}_{6}\right): 8.58$ (d, J $8.4 \mathrm{~Hz}, 1 \mathrm{H}), 8.37$ (brs, 1H), 7.64-7.62 (m, 2H), 7.26-7.22 (m, 1H), $7.16(\mathrm{~s}, 2 \mathrm{H}), 3.95(\mathrm{~s}, 6 \mathrm{H}), 3.93(\mathrm{~s}, 3 \mathrm{H}) \mathrm{ppm}$,

${ }^{13} \mathrm{C}$ NMR (100 MHz, DMSO-d $\left.\mathrm{d}_{6}\right)$ 165.3, 153.7, 142.1, 140.9, 134.5, 132.2, 129.2, 124.4, 121.1, 116.7, 104.7, 102.3, 61.1, 56.5 ppm, HRMS (ESI) Calcd. for $\mathrm{C}_{17} \mathrm{H}_{16} \mathrm{~N}_{2} \mathrm{O}_{4}[\mathrm{M}+\mathrm{H}]^{+} 313.1110$ Found 313.1185. 
2-(3,4-Dimethoxyphenyl)-3,4-dihydroquinazolin-4-one (4e). Solid, Yield 51\%, ${ }^{1} \mathrm{H} \mathrm{NMR}\left(400 \mathrm{MHz} \mathrm{CDCl}_{3}\right): \delta$ $7.96(\mathrm{~d}, J=6.4 \mathrm{~Hz}, 1 \mathrm{H}), 7.38-7.34(\mathrm{~m}, 1 \mathrm{H}), 7.23(\mathrm{brs}, 1 \mathrm{H}), 7.08-7.05(\mathrm{~m}, 1 \mathrm{H}), 6.94-6.88(\mathrm{~m}, 2 \mathrm{H}), 6.71(\mathrm{~d}, J=7.6 \mathrm{~Hz}$, 1H), $3.93(\mathrm{~s}, 6 \mathrm{H}) \mathrm{ppm},{ }^{13} \mathrm{C} \mathrm{NMR}\left(100 \mathrm{MHz}, \mathrm{CDCl}_{3}\right): \delta 164.8,150.4,149.6,147.3,134.0,130.9,128.7,120.1$, $119.7,114.5,110.9,109.8,69.0,56.0 \mathrm{ppm}$.

2-(4-Propylphenyl)-3,4-dihydroquinazolin-4-one (4f). Solid, Yield 61\%, $\left.{ }^{1} \mathrm{H} \mathrm{NMR} \mathrm{(400} \mathrm{MHz,} \mathrm{CDCl}_{3}\right): \delta 11.26$ (brs, 1H), 8.36 (d, J $7.6 \mathrm{~Hz}, 1 \mathrm{H}), 8.17(\mathrm{~d}, J 8.0 \mathrm{~Hz}, 2 \mathrm{H}), 7.86-7.79(\mathrm{~m}, 2 \mathrm{H}), 7.53(\mathrm{~d}, J 6.8 \mathrm{~Hz}, 1 \mathrm{H}), 7.42(\mathrm{~d}, J 8.4 \mathrm{~Hz}, 2 \mathrm{H})$, 2.74-2.70 (m, 2H), 1.78-1.69 (m, 2H), $1.02(\mathrm{~m}, 3 \mathrm{H}) \mathrm{ppm},{ }^{13} \mathrm{C}$ NMR (100 MHz, $\left.\mathrm{CDCl}_{3}\right): \delta 163.5,151.7,149.6$, $146.9,134.8,130.2,129.2,127.9,127.1,126.6,126.4,37.9,24.3,13.7$ ppm.

2-(4-tert-Butylphenyl)-3,4-dihydroquinazolin-4-one (4g). Solid, Yield 47\%, ${ }^{1} \mathrm{H}$ NMR (400 MHz, $\left.\mathrm{CDCl}_{3}\right): \delta 11.3$ (brs, $1 \mathrm{H}), 8.37$ (d, J=7.2 Hz, 1H), 8.20 (d, J 7.2 Hz, 2H), 7.87-7.80 (m, 2H), 7.63 (d, J 8.4 Hz, 2H), 7.54-7.50 (m, 1H), $1.41(\mathrm{~s}, 9 \mathrm{H}) \mathrm{ppm},{ }^{13} \mathrm{C} \mathrm{NMR}\left(100 \mathrm{MHz}_{\mathrm{CDCl}}\right): \delta 163.8,155.2,151.7,149.6,134.8,129.9,127.9,127.1$, $126.5,126.3,126.0,35.0,31.2 \mathrm{ppm}$.

2-(2,4,5-Trimethylphenyl)-3,4-dihydroquinazolin-4-one (4h). Solid, Yield 53\%, ${ }^{1} \mathrm{H} \mathrm{NMR}\left(400 \mathrm{MHz}^{\mathrm{CDCl}}\right): \delta$ 9.94 ( brs, 1H), 8.31 (d, J $8.0 \mathrm{~Hz}, 1 \mathrm{H}), 7.81(\mathrm{~d}, J 3.6 \mathrm{~Hz}, 2 \mathrm{H}), 7.53-7.49(\mathrm{~m}, 1 \mathrm{H}), 7.36(\mathrm{~s}, 1 \mathrm{H}), 7.12(\mathrm{~s}, 1 \mathrm{H}), 2.48(\mathrm{~s}$, $3 \mathrm{H}), 2.31(\mathrm{~s}, 6 \mathrm{H}) \mathrm{ppm},{ }^{13} \mathrm{C} \mathrm{NMR}\left(100 \mathrm{MHz} \mathrm{CDCl}_{3}\right): \delta 162.8,153.6,149.2,139.4,134.7,134.5,133.9,132.8$, $130.9,129.8,127.8,126.7,126.3,120.6,19.6,19.1,1.02 \mathrm{ppm}$.

2-(3-Phenoxyphenyl)-3,4-dihydroquinazolin-4-one (4i). Solid, Yield = 43\%, ${ }^{1} \mathrm{H} N M R\left(400 \mathrm{MHz}, \mathrm{CDCl}_{3}\right): \delta 11.38$ (brs, $\left.1 \mathrm{H}), 8.26(\mathrm{~s}, 1 \mathrm{H}), 7.99-7.95(\mathrm{~m}, 2 \mathrm{H}), 7.82-7.81(\mathrm{~m}, 2 \mathrm{H}), 7.58-7.10(\mathrm{~m}, 8 \mathrm{H}) \mathrm{ppm},{ }^{13} \mathrm{C} \mathrm{NMR}\left(100 \mathrm{MHz}^{\mathrm{CDCl}}\right)\right)$ $\delta$ 163.6, 157.8, 156.9, 151.0, 149.2, 134.9, 134.7, 130.4, 129.9, 128.0, 126.9, 126.4, 123.6, 122.2, 122.1, 118.9, $118.0 \mathrm{ppm}$.

\section{Acknowledgements}

We acknowledge the financial support from Department of Science and Technology, India (DST/INSPIRE/04/2017/000095).

\section{Supplementary Material}

The copies of ${ }^{1} \mathrm{H}$ NMR and ${ }^{13} \mathrm{C}$ NMR spectra of all synthesized compounds presented in the Supplementary Material.

\section{References}

1. Keilitz, J.; Malik, H. A.; Lautens, M. Topics in Heterocyclic Chemistry 2013, 32.

2. Schinzer, D.; Yunxin, B. Angew. Chem. Int. Ed. 1991, 30, 687.

https://doi.org/10.1002/anie.199106871

3. Nakamura, I.; Yamamoto, Y. Chem. Rev. 2004, 104, 2127. https://doi.org/10.1021/cr020095i

4. Ihara, M. Arkivoc 2006 (vii), 416. https://doi.org/10.3998/ark.5550190.0007.730

5. Shen, H.; Xie, Z. J. Am. Chem. Soc., 2010, 33, 11473. 
https://doi.org/10.1021/ja101796k

6. Lu, C.; Lu, X. Org. Lett. 2002, 26, 4677. https://doi.org/10.1021/ol0270733

7. Guanyinsheng, Q.; Jie, W. The Chemical Record 2016, 16, 19

8. Taylor, A. P.; Robinson, R. P.; Fobian, Y. M.; Blakemore, D. C.; Jonseb. L. H.; Fadeyi, O. Org. Biomol. Chem. 2016, 14, 661.

https://doi.org/10.1039/C6OB00936K

9. Vitaku, E.; Smith, D. T.; Niardarson, J. T. J. Med. Chem. 2014, 57, 10257. https://doi.org/10.1021/jm501100b

10. Randad, R. S.; Lubkowska, L.; Bujacz, A.; Naik, R. H.; Gulnik, S. V.; Yu, B.; Silva, A.; Munshi, S.; Lynch, T. M.; Clanton, D. J.; Bhat T. N.; Erickson, J. W. Bioorg. Med. Chem. Lett. 1995, 5, 2557. https://doi.org/10.1016/0960-894X(95)00449-4

11. Mhaske, S. B.; Argade, N. P. Tetrahedron 2006, 62, 9787.

https://doi.org/10.1016/j.tet.2006.07.098

12. Joseph, P. M. Nat. Prod. Rep. 2003, 20, 476.

https://doi.org/10.1039/b208140g

13. Bandekar, P. P.; Roopnarine, K. A.; Parekh, V. J.; Mitchell, T. R.; Novak, M. J.; Sinden, R. R. J. Med. Chem. 2010, 53, 3558. https://doi.org/10.1021/jm901847f

14. Chiou, W.; Liao, J.; Chen, C. J. Nat. Prod. 1996, 59, 374. https://doi.org/10.1021/np960161+

15. Liang, J. L.; Cha, H. C.; Jahng, Y. Molecules 2011, 16, 4861. https://doi.org/10.3390/molecules16064861

16. Mohameda, M. S.; Kamel, M. M.; Kassem, E. M. M.; Abotaleb, N.; Abd El-moez, S. I.; Ahmeda, M. F. Eur. J. Med. Chem. 2010, 45, 3311. https://doi.org/10.1016/i.ejmech.2010.04.014

17. Rhee, H.; Yoo, J. H.; Lee, E.; Kwon, Y. J.; Seo, H.; Lee, Y.; Choo, H. P. Eur. J. Med. Chem. 2011, 46, 3900. https://doi.org/10.1016/i.ejmech.2011.05.061

18. Ismail, M. A. H.; Barker, S.; Abou El Ella, D. A.; Abouzid, K. A. M.; Toubar, R. A.; Todd, M. H. J. Med. Chem. 2006, 49, 1526. https://doi.org/10.1021/jm050232e

19. Sharma, M.; Pandey, S.; Chauhan, K.; Sharma, D.; Kumar, B.; Chauhan, P. M. S. J. Org. Chem. 2012, 77, 929.

https://doi.org/10.1021/jo2020856

20. Kanışkan, N.; Kökten, S.; Celik, I. Arkivoc 2012 (viii), 198.

http://dx.doi.org/10.3998/ark.5550190.0013.818

21. Giri, R.; Lam, J. K.; Yu, J-Q J. Am. Chem. Soc. 2010, 132, 686.

https://doi.org/10.1021/ja9077705

22. Dabiri, M.; Salehi, P.; Baghbanzadeh, M.; Zolfigol, M. A.; Agheb, M.; Heydari, S. Catal. Commun. 2008, 9, 785.

https://doi.org/10.1016/i.catcom.2007.08.019.

23. Dabiri, M.; Salehi, P.; Otokesh, S.; Baghbanzadeh, M.; Kozehgarya, G.; Mohammadi, A. A. Tetrahedron Lett. 2005, 46, 6123.

https://doi.org/10.1016/i.tetlet.2005.06.157 
24. Yoo, C. L.; Fettinger, J. C.; Kurth, M. J. J. Org. Chem. 2005, 70, 6941. https://doi.org/10.1021/jo050450f

25. Wang, J-M, Jiang, X., Zhang, Y., Zhu Y-M, Shen, J-K. Tetrahedron Lett. 2015, 56, 2349. https://doi.org/10.1016/i.tetlet.2015.03.121

26. Fang, W.; Deng, Q.; Xu, M.; Tu, T. Org. Lett. 2013, 15, 3678. https://doi.org/10.1021/ol401550h

27. Markovič, M.; Lopatka, P.; Koóš, P.; Gracza, T. Org. Lett. 2015, 17, 5618. https://doi.org/10.1021/acs.orglett.5b02840

28. Gadge, S. T.; Bhanage, B. M. Synlett, 2014, 25, 85. https://doi.org/10.1055/s-0033-1340162

29. Mane, R. S.; Bhanage, B. M. J. Org. Chem. 2016, 81, 1223. https://doi.org/10.1021/acs.joc.5b02385

30. Gockel, S. N.; Hull, K. L. Org. Lett. 2015, 17, 3236. https://doi.org/10.1021/acs.orglett.5b01385

31. Ren, W.; Yamane, M. J. Org. Chem. 2010, 75, 8410. https://doi.org/10.1021/jo101611g

32. Qiu, G.; Dingb, Q.; Wu, J. Chem. Soc. Rev. 2013, 42, 5257. https://doi.org/10.1039/c3cs35507a

33. Jiang, X.; Tang, T.; Wang, J-M; Chen, Z.; Zhu, Y-M; Ji, S-J. J. Org. Chem. 2014, 79, 5082. https://doi.org/10.1021/j0500636y

34. Tyagi, V.; Khan, S.; Giri, A.; Gauniyal, H. M.; Sridhar, B.; Chauhan, P. M. S. Org. Lett. 2012, $14,3126$. https://doi.org/10.1021/ol301131s

35. Tyagi, V.; Khan, S.; Chauhan, P. M. S. Synlett 2013, 24, 0645. 